\title{
Émigré Albert Eckstein's Legacy on Health Care Modernization in Turkey: Two Generations of Students Who Have Made Major Contributions
}

\author{
Çimen Günay-Erkol and Arnold Reisman
}

\section{Introduction}

$\mathrm{D}$ uring the 1920s, Turkey witnessed a maelstrom of radical reforms and with the abolition of the caliphate on 3 March 1924 the country took giant steps to become a secular state with all its ramifications. On the same day, another revolutionary law aiming at unification, standardization, and secularization of the educational institutions (Tevhid-i Tedrisat kanunu) was passed. This law closed the religious schools and attached all educational institutions to the Ministry of National Education. ${ }^{1}$ Several other reforms in education followed with speed. The Latin based alphabet was mandated by law on 1 November 1928, significantly increasing literacy within a short time frame. ${ }^{2}$ The most significant reform to the subject at hand came in 1933. Turkey's system of higher education, including medical education, was thoroughly revised when the University Reform Law No. 2252 was passed on 31 May 1933. It abolished the Istanbul Darülfünun, an academy based on the Islamic tradition of higher education derived from the medieval medrese, and turned into a university during the first decade of the $20^{\text {th }}$ century. $^{3}$

1 Yasemin Karakaşoğlu, “Turkey”, in Wolfgang Hörner, Hans Döbert, Botho von Kopp, and Wolfgang Mitter, eds., The Education Systems of Europe, (Amsterdam, 2007), pp. 783-807.

2 Adoption of Latin alphabet increased the percentage of literacy in Turkey, from $9 \%$ in 1924 to $65 \%$ in 1975 to $82.3 \%$ in 1995. See Geoffrey Lewis, The Turkish Language Reform: A Catastrophic Success (Oxford, 1999). For an essay and 17 photos depicting the process of implementing the edict, see M. O. Williams, "Turkey Goes to School”, The National Geographic Magazine (January 1929), pp. 94-108.

3 Darülfünun means "house of arts and sciences" or the house of knowledge. 
In this attempt at remodeling, the young Republic of Turkey radically revised and expanded the Ottoman reforms. It was the Ottoman State, which initiated the establishment of Darülfünun as an institution for higher education on 23 July 1846. Darülfünun was closed and re-opened many times due to pressure of traditional circles and counter-pressure from Westernist bureaucrats and intellectuals. This first Darülfünün was closed and reopened on 20 February 1870 as Darülfünun- $i$ Osmani, in 1874 as Darülfünun-u Sultani, and in 1900 as Darülfünun-u Şahane (Imperial University). Bernard Lewis refers to the Darülfünun-u Şahane as "the first modern university in the Islamic world". ${ }^{4}$ After the Young Turk reform in 1908, the Darülfünun was named as Darülfünun-i Osmani again and on 20 April 1912, Istanbul Darülfünun was established.

Medical education was first institutionalized within the Ottoman Empire when a School of Medicine known as the Tiphane-i Amire and a School of Surgery, the Cerrahhane-i Amire, were founded on 14 March 1827, to provide higher quality health care to its army. ${ }^{5}$ In 1867, a civil Medical School, the Mekteb-i Tibbiye-i Mülkiye was established. There is a gap of knowledge about the training of physicians in provincial Ottoman medreses but history of medical training at modernized institutions is relatively well researched and documented. These institutions were not coeducational. Women had to wait to pursue higher education until 1842, when a School of Midwifery linked to the Military Academy was initiated. In 1869, a Women's School for Fine Arts the İnas Sanayi-i Nefise and in 1914, Women's University Inas Darülfuinun were founded. Women were granted access to their Faculty of Medicine in 1922. ${ }^{6}$ The overwhelmingly male-dominated structure of health personnel during the late Ottoman and early Republican eras gradually changed as the number of doctors grew from 554 in 1923, to 1182 in 1930 and 2387 in 1940, at which time Turkey's population was about 18 million.

Between 1915-1918, several scientists invited from abroad lectured at the Istanbul Darülfünun. ${ }^{8}$ During this period, it was also a common practice for the Ottoman State to send students to central Europe for internship or higher education, in

4 Bernard Lewis, The Emergence of Modern Turkey (Oxford, 1968), p. 182.

5 Bedii Şehsuvaroğlu et al., Türk Tip Tarihi [History of Turkish Medicine] (Bursa, 1984), pp. 185-168.

6 Nuran Yıldırım, ed., Sağlık Alanında Türk Kadın: Cumburiyet'in ve Tip Fakültesi'ne Kız Ögrenci Kabulünün 75. Yilı [Turkish Women in Medicine: 75th Anniversary of the Republic and the Access of Girls to the Faculty of Medicine] (İstanbul, 1998).

7 B. Serdar Savaş et al., "Health Care Systems in Transition: Turkey", European Observatory on Health Care Systems 4 (2002), p. 16.

8 For a list of those scientists, See Horst Widmann, Atatürk ve Üniversite Reformu [Atatürk and the University Reform] (İstanbul, 2000): pp. 62-63. Also see Mustafa Gencer, Jöntürk Modernizmi ve "Alman Ruhu”: 1908-1918 Dönemi Türk-Alman Iliş̧kileri ve Eğitim [Jeunne Turc Modernism and "German Spirit": Turkish-German Relations and Education between 1908-1918] (İstanbul, 2003). 
order to maintain cadres of well-educated bureaucrats. ${ }^{9}$ The student and teacher exchange between Turkey and Europe in the field of education continued into the Republican period. On the first anniversary of the Republic in 1924, Turkey organized a central examination and started to send some of her brightest to Europe for graduate and post-graduate study. Young graduates came back to serve as teachers and science mentors. ${ }^{10}$

In 1933, at the 10th anniversary of the Republic, a giant reformative step was taken in the establishment of the İstanbul University as the first modern and coeducational university in Turkey. 157 of the 240 of Darülfünun's faculty members were relieved of their duties, and forced into retirement. ${ }^{11}$ This reform was in fact the result of a three-year effort, initiated in 1931 through the invitation of Professor Albert Malché (1876-1956) from Geneva for evaluating the Darülfiinun, and writing a report on modernization of Turkey's higher education system. Malché arrived on 16 January 1932, and submitted his report to the Ministry of Education on 1 June $1932 .{ }^{12}$ Based on that report reforms were implemented albeit under influence of the political party in power. During the deliberations of the First Turkish History Congress in 1932, when some Darülfünun professors criticized the regime's official views in matters of history and language, two fundamental aspects of the young Republic's politics of culture, the existing higher education faculty became perceived as an obstacle to the cultural reforms planned by the Republican cadres. ${ }^{13}$ Most of the scholars who had been dismissed from their positions as part of the 1933 reform found themselves as outsiders of Republican politics, except for a few figures, who later obtained very important positions in the subsequently established universities. ${ }^{14}$

9 Selçuk Akşin Somel, The Modernization of Public Education in the Ottoman Empire 1839-1908: Islamization, Autocracy and Discipline (Leiden, 2001).

10 Students of many different fields of study, from Natural Sciences to Fine Arts and Archeology, obtained the chance to study abroad. Among them, there were students from the Faculty of Medicine like Osman Cevdet Çubukcu and Kamile Şevki Mutlu as well, who later became pioneers in Turkish medicine. See Kansu Şarman, Türk Promethe'ler: Cumburiyet'in Ögrencileri Avrupa'da [Turkish Promethes: Students of the Republic Are in Europe] (İstanbul, 2005): pp. 207-313.

11 İlhan Elmac1, “Dr. Rudolph Nissen”, Journal of Neurological Sciences (Turkish) NOROL BIL D, 18, (2001).

12 Mustafa Kemal Atatürk's hand written notes on Malche's report show that one of the greatest concerns of the reform was to sustain the freedom and at the same time the accountability of higher education. See Utkan Kocatürk, "Atatürk'ün Eğitim Reformu ile İlgili Notlar1 [Atatürk's Notes on the University Reform]", Atatürk Arasttrma Merkezi Dergisi, 1, (November 1984).

13 İlhan Başgöz and Howard E. Wilson, Educational Problems in Turkey: 1920-1940 (Bloomington, 1968).

14 İsmail Hakkı Baltacıoğlu, the famous pedagogue who was ousted from his post in Darülfünun in 1933 later became an adviser to Mustafa Kemal on religious reforms and issues. See 
The contemporaneous tragedy of the expulsion of Jewish and/or anti-Nazi citizens from Germany's institutions in 1933 caused the scientists, to seek refuge in foreign countries. One of the least known of these safe havens was the Republic of Turkey. The tragedy turned into an opportunity for some 190 eminent intellectuals, who were invited to Turkey by the government, an act that saved their lives. ${ }^{15}$ The émigrés invited to live, teach and practice in Turkey were specialized in a wide range of sciences and professions. However, as Philipp Schwartz stated in his memoirs, it was the medical sciences, which employed the largest number of émigrés. ${ }^{16}$ The greater number of invited scientists were physicians because they were the most needed in post-war Turkey. Having lost about one-fifth of the population in the battlefields of World War I, the country was struggling to mobilize qualified human power. When the Istanbul University was founded in 1933, directors of eight out of the twelve of its medical institutes were émigré professors. When compared to other universities in Europe, in 1933 Istanbul University had the greatest number of Jewish German refugees as faculty. At that time, it was widely considered "the best German University in the world". ${ }^{17}$ Schwartz also noted that, the infamous Scurla had mentioned in his 1939 spying report ${ }^{18}$ that İstanbul University was "a school turned Jewish". ${ }^{19}$

Nazım İrem, "Turkish Conservative Modernism: Birth of a Nationalist Quest for Cultural Renewal", International Journal of Middle East Studies, 34, (2002), pp. 87-112.

15 One way to recognize the caliber of people involved is to note that prior to, during, and after their exile in Turkey at least sixteen of them are known to have corresponded with Nobel laureates including Max Von Laue, James Frank, Linus Pauling, Max Planck, Max Born, Erwin Schroedinger, Neils Bohr, Enrico Fermi, Herman J. Muller, Albert Szent-Györgyi, Bertrand Russell and Albert Einstein. See Arnold Reisman, Turkey's Modernization: Refugees from Nazism and Atatürk's Vision (Washington, DC, 2006): p. 468.

16 Philipp Schwartz, Kader Birliği: 1933 Sonrası Türkiye’ye Göç Eden Alman Bilim Adamlar [German Scientists Who Immigrated to Turkey After 1933] (İstanbul. 2003): pp. 1824.

17 Extracted from statement of Mr. Onur Öymen, member of Grand Assembly of Turkey, at the Seminar on "Culture as a Weapon, Academicians in Exile" in Berlin on July 19, 2003.

18 Herbert Scurla was an officer of the Ministry of Science Education of Hitler Germany. See Ibid., 15:34. It is thanks to a coincidence that the German historian Hans Detlef Grothusen whilst carrying out his investigations as curator of an exhibition about German-Turkish relations (on the occasion of the Centenary of the Birth of Atatürk 1981), came across the report by Herbert Scurla amongst the piles of embassy records from 1924-1938. In May 1939, in possession of a wealth of Gestapo material, under orders from "The Reich Ministry for Science, Education and National Education" he undertook a trip to Turkey. The purpose of the trip was to inspect the activities of the German university lecturers in Turkey, a few of which had been officially sent there and were loyal to the regime, the majority, however, were made up of political refugees, who from the Turkish standpoint were given preference in obtaining employment when they applied for a position. 
This paper focuses on the sojourn of the noted pediatrician Albert Eckstein in Turkey within the greater history of the 1933 university reform and the invitation of émigré professors by the Turkish government. The paper documents the respect and gratitude for Eckstein and shows his influence on Turkey's modernization of her health care systems through İhsan Doğramacı and in turn Burhan Say, a lineage of two of the most famous Turkish pediatricians whose work honors Professor Eckstein's legacy. İhsan Doğramacı is a leading figure in pediatrics and also a pioneer in health care and education in Turkey. ${ }^{20}$ Burhan Say is a prominent pediatrician and genetecist, who built a bright career in the field, having taken his residencies at Hacettepe University and in the United States. They represent two generations of Turkish medicine each of whom has made a major impact on the field worldwide, but more significantly on pediatrics as it is practiced in Turkey today.

Medical professionalization, public health, and the improvement of health care delivery systems were intricately tied to the consolidation of the State during the 1930s. Bringing professional health care to the doorsteps of the people wherever they maybe, was considered the primary means of creating a widespread sense of equality in the society. This was intended to consolidate the social structures, as well as the citizens' trust in the State. In the initial years of the Republic, there was also a pro-natalist policy being supported by the government with a series of laws. Abortion was illegal as of 1926, when the Italian Penal Code was adapted to organize the definition of health care in the constitution, sale of contraceptives was also restricted and childbearing values were supported at the societal level. ${ }^{21}$ Children's health was a key issue for the nascent state, since they were seen as the future of the country. ${ }^{22}$ Therefore, issues about children's health were in a more critical position than other aspects of medical care in 1930s Turkey.

Focusing at the careers of three pediatricians Eckstein, Doğramacı and Say, within the broader picture of the transformation of healthcare and education policies in Turkey since the1930s, this paper presents a Turkey-oriented history of continuity and change. The experiences of the émigré professors in Turkey, as obtained from their memoirs or from the accounts provided by their students, not only make an influential contribution to the international literature of reform efforts in medi-

http://www.museumonline.at/1999/schools/classic/istanbul/exilturkei e.htm Viewed June 13, 2007. Also see Faruk Şen, Ay-Yildiz Altında Sürgün (Exiled under the Star and Crescent) (İstanbul, 2008.)

19 Ibid., 16.

20 At the time of this writing he is the only surviving signatory of the World Health Organization's Charter.

21 Frederic C. Shorter, "Turkish Population in the Great Depression", New Perspectives on Turkey, 23, (Fall 2000), pp. 103-124.

22 Olcay Neyzi, "Türkiye'de Cumhuriyetin 761nc Yllında Pediyatri [Pediatrics in the 76th Anniversary of the Republic in Turkey]", Proceedings of TÜBA, (Ankara, 1999). 
cal education and health care delivery, but also shed light to a relatively less explored part of the history of the World War II. The caliber of the intellectuals who were saved by Turkey, has for over 70 years remained a blind spot in the Anglophone literature of intellectual history especially considering their respective roles in the history of science, the professions, and the humanities. ${ }^{23}$ Memories of the émigré professors and the appreciation of their contributions to Turkey's modernization linger on in the country. This topic is of particular relevance set against the current backdrop of Turkey's tug of war and her sustained efforts to enter the European Union while struggling to remain a secular state within a democratic framework with a predominantly traditional Islamic population and surrounded by hostile theocracies.

By the time Albert Eckstein arrived in Ankara, the city was a capital with most of its plans still on paper. Clinics were inadequate, and there was no modern pediatrics institute. Medicine and health services were confined to the narrow limits of the city centers and had not yet reached out towards a larger population. The period during which Doğramac1 actively worked as a pediatrician witnessed the growth of the modern Turkish higher education system as well as the enhancement of its health care delivery system. In 1945, the Social Insurance Foundation (Sosyal Sigortalar Kurumu, SSK) was established. Critical changes took place after a series of new universities were opened in the 1950s such as the Karadeniz Technical University in Trabzon, Ege University in İzmir, Middle East Technical University in Ankara, and Atatürk University in Erzurum. ${ }^{24}$

During Say's career in Turkey, an understanding of modern health care was established in the society from top to bottom. The Nationalization of Health Care Delivery Law (Law No. 224) passed in 1961, integrated public health services and established the State's acknowledgement of every citizen's right to access proper health care. The development continued in many parts of the country resulting in a relatively high quality of clinical health care. When Say published an article on a new syndrome ultimately named after him in 1968 (the Say syndrome), ${ }^{25}$ there were already a considerable number of well established pediatrics clinics in Turkey and generations of proficiently educated young doctors.

The improvements achieved in medical education and the health sector since 1930s are very important but there still are significant inequalities among regions in

23 Arnold Reisman, "Turkey's Invitations to Nazi Persecuted Intellectuals Circa 1933: A Bibliographic Essay on History's Blind Spot," A working paper available at http://ssrn.com/abstract=993310 and Ibid., 15 forthcoming in Covenant, The global Jewish magazine.

24 Himmet Umunç, "In Search of Improvement: The Reorganisation of Higher Education in Turkey", Minerva, 4, (December 1986), pp. 433-455.

25 Burhan Say and P, S. Gerald. "A new polydactyly/imperforate anus/vertebral anomalies syndrome?” Lancet, 2, (1968), p. 688. 
Turkey, and it cannot be said that the goal of the Alma-Ata declaration "Health for all in 2000 " has been reached. ${ }^{26}$ It is still open to debate whether the nationalization of health services has been successful. ${ }^{27}$ Going back in time to the speedy transformations in education, law and health care within the generic framework of the 1933 reform, this paper will try to shed more light into the initial steps of these reform efforts. It will bring the legacy of the émigré professors in the modernization of Turkey to the fore and comment on the contributions of Albert Eckstein.

The legacy of the émigré professors recently attracted public attention in Turkey following the discovery of a letter in the archives, written by famous physicist Albert Einstein to İsmet İnönü, asking him to accept 40 German intellectuals, who were ready to come and work for one year at no pay. ${ }^{28}$ On 29 October 2006, when Turkey celebrated its 83rd anniversary as a Republic, this letter appeared as a firstpage story in Hürriyet, the highest circulation Turkish daily. ${ }^{29}$ For the citizens of Turkey, a country which has sent thousands of workers to Germany since the end of World War II, it was surprising to be reminded that about seventy years earlier, Turkey was a destination for some German citizens who applied for jobs and political asylum. ${ }^{30}$

This article kindled renewed interest in the 1933 émigrés and their reception in Turkey. Thus within a week of the Bardakçı article, Melih Aşık published an article in Milliyet, another mass-circulation newspaper, which juxtaposed the attention given by Turkish media to the Einstein letter with the unawareness of this episode outside of Turkey. The discussion was continued in an article published in yet another high circulation Turkish daily, Sabah. Umur Talu emphasized that the reform was a product of the famous Professor of Pedagogy Albert Malché, who reported on the Turkish higher education system. Talu also discussed how the émigré scientists saw Turkey as a safe haven, quoting from Philipp Schwarz's first

26 http://www.who.int/countryfocus/resources/ccsbrief turkey tur 06 en.pdf.

27 Unequal access to preventive health care services in Turkey can be identified by the high infant mortality rate. Ibid., 7:15.

28 Arnold Reisman, "What a Freshly Discovered Einstein Letter Says About Turkey Today," HNN, http://hnn.us/articles/31946.html. Posted November 27, 2006. For a clearer image of the letter see http://armenians-1915.blogspot.com/2006/11/1243-what-freshly-discoveredeinstein.html. Also see Arnold Reisman, "Jewish Refugees from Nazism, Albert Einstein, and the Modernization of Higher Education in Turkey (1933-1945)", Aleph: Historical Studies in Science \& Judaism, 7, (2007), pp. 253-281. http://inscribe.iupress.org/doi/abs/10.2979/ALE.2007.-.7.253

29 The headline by Murat Bardakçı reads: "A Request from the Great Genius to the Young Republic."

30 Because Turkey was officially a neutral country many of these émigrés acted as conduits of communication between colleagues, friends, and relatives left behind and those in the free world. Arnold Reisman, "German Jewish Intellectuals' Diaspora in Turkey: (1933-1955)", The Historian, Published on behalf of Phi Alpha Theta History Honor Society, 69, (2007), pp. 450478. 
impressions of the country in his memoirs, where Schwarz wrote that Turkey was "a wonderful country where the Western plague of fascism had not penetrated". ${ }^{31}$ Soon after Malché submitted his report to the Ministry of Education, the government negotiated for 30 professorship chairs. ${ }^{32}$ The invitations gradually extended to Nazi-persecuted German and Austrian intelligentsia, among which was the acclaimed pediatrician Albert Eckstein. ${ }^{33}$

\section{Albert Eckstein in Turkey}

Albert Eckstein was born on 9 February 1891 in Ulm, Germany. He studied medicine in Freiburg, served in the First World War, and was awarded the eisernes Kreut, the German Honour Cross, First Class, for his heroic service. ${ }^{34}$ After the war, Eckstein worked at the Physiology Institute of the University of Freiburg and in 1920, he transferred to the University Hospital for Children to work under the pediatrician Carl T. Noeggerath (1876-1952). On 1 October 1925, in the city of Duesseldorf, he married Erna Schlossmann (1895-1998), a pediatrician and daughter of Arthur Schlossmann (1867-1932), who, too, was a pediatrician and head of the Children's Hospital at the Academy of Medicine in Dusseldorf. In 1926, Eckstein was promoted to Professor. After Schlossmann's death, Dr Eckstein was appointed chief of the department. ${ }^{35}$ However, on 1 July 1935, while in his Düsseldorf clinic Dr. Eckstein received an envelope marked "Personal." It said: "In the name of the Reich, I relieve you of your duties in the service of the Prussian Government by June 1935, based on the orders dated 12 June 1935. Adolph Hitler, Hermann Göring". ${ }^{36}$

Through the Emergency Organization for German Scientists Abroad, the Ecksteins received an offer from the Turkish Government to work at the Ankara Numune Hospital, the largest hospital of the city at the time. ${ }^{37}$ The contract was

31 Umur Talu, “On University Reform”, Sabah Newspaper, October 30, 2006.

32 Ernst Eduard Hirsch, Anılarm [My Memoirs] (Ankara, 1997), p. 190.

33 For a list of 715 pediatricians in 1933 in Germany, in 1938 in Vienna, and at German children's hospitals in Prague, see Anonymous "Die Verfolgten/The persecuted", Monatsschrift Kinderheilkunde, 13. (May 1999), pp. 6-11.

34 Nejat Akar, Anadolu'da bir Çocuk Doktoru [A Pediatrician in Anatolia] Ord .Prof. Dr. Albert Eckstein (Ankara, 2003.)

35 Nejat Akar, "Albert Eckstein: a pioneer in pediatrics in Turkey", Turkish Journal of Paediatrics, 46, (2004), pp. 295-297.

36 Moll H, Emigrierte Deutsche Padiater: Albert Eckstein, Werner Solmitz. Monatsschr Kinderheilkd 143, (1995), pp. 1204-1207.

37 Organized by Philipp Schwartz. See Philipp Schwartz, Notgemeinschaft Zur Emigration deutscher Wissenschaftlernach 1933 in die Turkei, (Marburg: 1995). Schwartz a physician of note organized the Notgemeinschaft in Switzerland to help scientists who lost their jobs to find 
signed in Berlin on 1 August 1935 by Hamdi Arpağ, Turkey's ambassador to Germany ${ }^{38}$ and the family arrived during September 1935 in Ankara in a city of 122.720 people. ${ }^{39}$ Ankara's development was considered synonymous with the new regime's success. It became home to famous émigrés such as Georg Rohde, Professor of Philology of Ancient Languages and Ernst Reuter, former member of the German Parliament who escaped via Holland to England after spending two years in a concentration camp before coming to Ankara. It was also the home for Paul Pulewka considered the father of Turkey's pharmacology. ${ }^{40}$

Figure 1. Professor Albert Eckstein

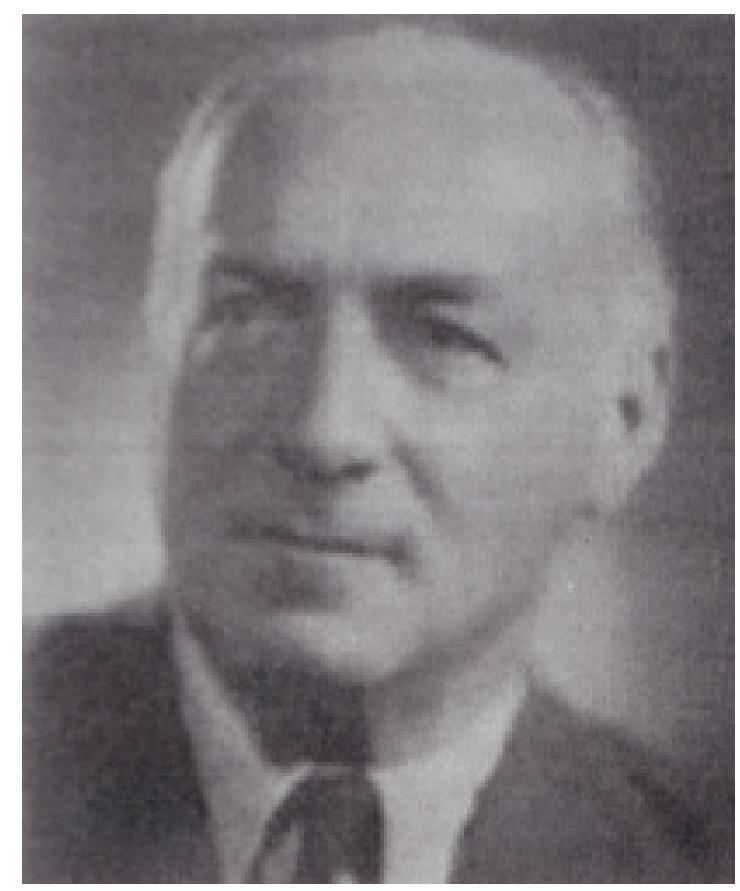

employment elsewhere. Schwartz was asked to identify German-speaking professors to whom the Turkish government should extend invitations with a mandate to modernize its universities. This he did during July 1933. Schwartz's father-in-law was Professor Sinai Tschulok (1875-1945), who had taken refuge in Switzerland after the 1905 Russian revolution. He was a good friend of Albert Malché. At the time, persecution of German scientists had already begun in Germany. It seems Malché saw the double opportunity and got in touch with Schwartz. Some 700 intellectuals were thus saved: see Arnold Reisman Ibid., 15:9.

38 Albert Eckstein's Private File from Ankara Numune Hospital. Official private file of Ord. Prof. Dr. Albert Eckstein, Ankara Numune Hastanesi, [Ankara Numune Hospital] 19351945. Official private file, 1945 Official private file of Ord. Prof. Dr.Albert Eckstein, Ankara Medical Faculty, 1945-1949.

39 State Institute of Statistics. Census of Population by Administrative Division. Publication No. 537 (24.10.1965).

40 Arin Namal and Arnold Reisman, "Paul Pulewka Founder of Turkey's Pharmacology While in Exile from the Nazis: 1935-1955", (2007), Forthcoming in the Journal of the International Society for the History of Islamic Medicine (ISHIM). 
The first assignment given to Eckstein by Refik Saydam, the head of the Ministry of Health and Social Assistance, involved a wide scale investigation of rural child mortality. During the first decade of the Turkish Republic, the infant mortality rate was very high. Nearly one of three children born was at risk with a near certainty of death. ${ }^{41}$ Hence the government was greatly concerned with preventive measures to decrease this rate. The Ministry of Health and Social Assistance asked Dr. Albert Eckstein to undertake a trip, accompanied by Eckstein's newly assigned assistant, Dr. Selahattin Tekand, during July and August 1937 to investigate children's diseases and mortality in thirteen central and southern Anatolian provinces and villages. Erna Eckstein accompanied her husband as well, although by law she was not allowed to work in Turkey even as a volunteer. In the summer of 1938, another trip was organized. During these sojourns, the Ecksteins became immersed in diverse and widely dispersed rural communities, meeting the locals and gaining acceptance. They examined numerous children, asked questions of the families, and provided the villagers some basic medications. ${ }^{42}$

The result of the Ecksteins' demanding expeditions in the villages of Anatolia was that the overall child mortality fell from $33 \%$ to $12 \% .{ }^{43}$ This was a major accomplishment indeed and is widely credited to Eckstein's work, his leadership, and the guidance he provided. In addition to the considerable reduction in child

41 See the 2003 Turkey Demographic and Health Survey (TDHS-2003) for more recent figures of child mortality rates. http://www.hips.hacettepe.edu.tr/tnsa2003eng/index.htm

42 Dr. Erna Eckstein-Schlossmann, also a pediatrician, accompanied her husband on all data collection field trips. In 1954, four years after her husband's death, Dr. Erna EcksteinSchlossmann came back to Turkey and helped to the establishment of the Child Health Institute in Ankara. She took over housekeeping in the hospitals overseeing the kitchens, laundry, etc. and ordering equipment from Germany until 1961. Her son Herbert Eckstein also came to Turkey later in 1960s, when the Child Health Institute grew into the Hacettepe University, and contributed to the development of pediatric surgery including urology and orthopaedics.

43 Eckstein-Schlossmann E. Memories of Turkey. Unpublished pages. 46. Typewritten pages, Private notes. Cambridge; 1975. [Available through Professor Nejat Akar,] Professor Eckstein A. Köyde Hayat, [Village Life] ULUS, 8-9 Sonteşrin.1937, Ankara, and Eckstein A. Anatolian Impressions, Private notes. 1938 [Available through Professor Akar]; Many fertility, infant and child mortality estimates have been offered for those years. However, Eckstein's visits represented the first attempt to collect data from a large sampling. It is not clear what was meant by infants and children, i.e. which age groups. Also an average for Turkey at that time, as is true now, is not to be taken too seriously. Eckstein did not visit eastern Anatolia, the real backwater. So even more than $50 \%$ infant mortality may have been true for the East while the lower figure of $33 \%$ given in (Widmann H. Atatürk ve Üniversite Reformu. [Atatürk and the University Reform] Çeviri: [Translation] A. Kazancigil, S. Bozkurt. İstanbul Üniversitesi Cerrahpaşa Tıp Fakültesi Atatürk'ün Yüzüncü Doğum Yılını Kutlama Yayınları, [Commemorative Publications of Istanbul University, Cerrahpaşa Medical School, on the centenary of Atatürk's birth] İstanbul: Özel Seri 3, 1981 may be true for the wealthier parts of Anatolia. Nejat Akar, Aysu Oral, and Arnold Reisman, "Modernizer of Turkey's Pediatrics: Albert Eckstein in exile", Journal of Medical Biography, 15, (2007), pp. 213-218. 
mortality rate, another success of Eckstein was the eradication of Noma, a disease directly related to malnutrition and poor hygiene, the victims of which were mostly children. Eckstein became so fluent in Turkish that he even authored a pediatrics textbook in this language. His 1941 book Çocuk Neşvünema, Tegaddi ve Metabolizmasinin Fiziyoloji ve Patolojisi was an important contribution to Turkish pediatrics in general, and to child development and metabolism in particular. ${ }^{44}$ The Ministry of Health distributed it to all medical doctors in Anatolia, and it was used as part of the medical school's curriculum for many years. Another important book by Eckstein was Türkiye'de Çocuk Hastalıkları ve Çocukların Korunması Problemleri published by Ankara University Faculty of Medicine. ${ }^{45}$

Two letters published in the daily Cumburiyet showed how his patients considered Albert Eckstein as an impressive symbol of professional health care. Jülide Gülizar indicated that the name Eckstein was a keyword for mothers of all ages in Ankara during the time he worked at the Numune Hospital. She writes: "He left behind a lot of research and studies about Turkish children and the special throne he had built in the hearts of their mothers" ${ }^{46}$ Another testimonial from Ali Riza Erkan, whose son was treated by Albert Eckstein and saved from a serious bronchopneumonia, carried similarly warm overtones. Erkan wrote how he found the chance to express his gratitude to Herbert Eckstein, the eldest son of the family, who later became Professor of Pediatric Surgery at the Great Ormond Street Children's Hospital in London:

At the cocktail in Ankara Palas given for the delegates participating in the congress, I learnt that a son of the hoca ${ }^{47}$ who himself was a physician was also there. I requested a physician of my acquaintance who spoke German to tell him that his father had saved my son's life and to convey my thanks and gratitude. Among the numerous pediatricians trained by this friend of Turkey are also physicians who work in the fields of childhood health and administration. ${ }^{48}$

During the years he spent in Turkey, Eckstein also served as a member of the Editorial Board of Annales Paediatrici (1938/1939), a leading pediatrics journal in Europe. In October 1938, he organized the first Turkish Pediatrics Congress in An-

44 Albert Eckstein, H. Tekiner and N. Özlem, Çocuk Neşvünema, tegaddi ve metabolizmasinin fiziyoloji ve patolojisi [Physiology and Pathology of Childhood Development, Nutrition and Metabolism] (Ankara: 1941).

45 Albert Eckstein, Türkiye'de Çocuk Hastalılar ve Çocuklarn Korunması Problemleri [Children's Illnesses and Problems about Child Protection in Turkey], (Ankara: 1947)

46 Jülide Gülizar, "My Ankara”, Cumhuriyet, 28, November 1989.

47 A still used but old and affectionate Turkish term for a respected teacher.

48 Ali Riza Erkan, "Letter to Cumhuriyet", Cumburiyet, 9 December 1989. 
kara, and published two exclusive pediatrics textbooks in Turkish, Çocuk Sağglğr Ders Kitabı and Süt Çocuğu Hastalıkları Ders Kitabı. ${ }^{49}$

Figure 2. Türkiye'de Nüfus Siyasetine ve İçtimai Hijyene Ait Meseleler İle Bunların Çocuk Hekiminin Vazifesi Noktai Nazarından Tetkiki by Prof. Albert Eckstein.

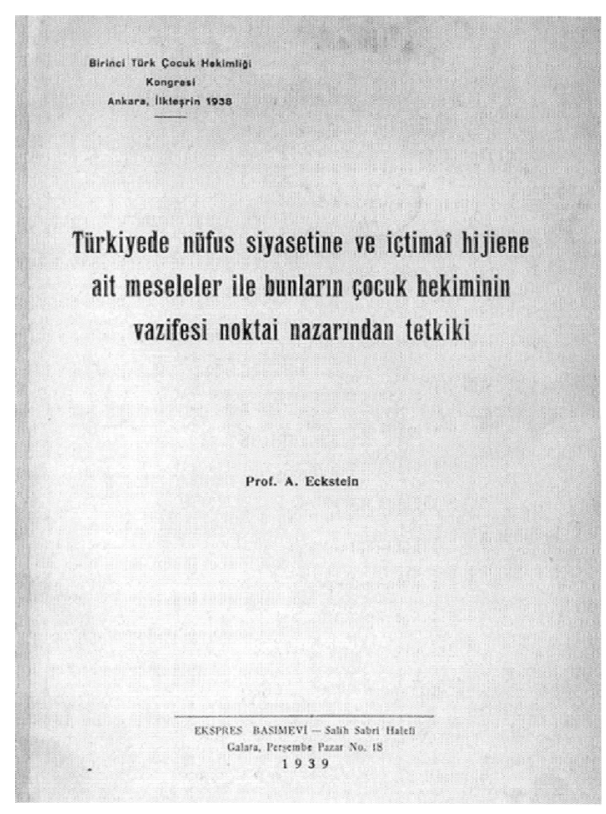

Eckstein contributed significantly to implementation of modern public health and pediatrics practices in Turkey. He did not limit himself only to the Numune Hospital and to medical research, but made major contributions to the treatment of children's illnesses, by "establishing institutes and clinics for Turkish children, mainly in rural areas". ${ }^{50}$ As fortuitous as the timeliness of Eckstein's arrival for Turkey had been, so was his voluntary departure. On 22 June 1948, he was invited to the Ludwig Aschoff in Freiburg University. In 1950, he left Turkey, to serve as the Director of the University Children's Hospital in Hamburg. The critical mass of Turkish pediatricians trained in modern medicine, essential for sustained takeoff, had been developed by the late 1940s. ${ }^{51}$ With less world acclaim then that accorded to their émigré mentors, yet filling a great need, the early graduates of Ankara University's medical school became Turkey's most revered practitioners and professors.

49 Albert Eckstein, Türkiye'de Nüfus Siyasetine ve İçtimai Hijyene Ait Meseleler İle Bunların Çocuk Hekiminin Vazifesi Noktai Nazarından Tetkiki. [Population Policy and Public Hygiene Problems in Turkey and Their Investigation from the Viewpoint of a Paediatrician's Duties] Birinci Türk Çocuk Hekimliği Kongresi. [First Symposium of Turkish Paediatrics] (İstanbul: 1938).

50 Stanford J. Shaw, Turkey and the Holocaust, (London,1993), p. 367.

51 Ibid., 34.

52 Among these were many of Eckstein's students. 
In discussing Albert Eckstein, one of his colleagues, professor of Medical Law Behçet Tahsin Kamay said:

He reached the remotest corners of Anatolia [Asia Minor part of Turkey] and he walked over every inch of the land. He visited the villages and went among the villagers; he knocked on their doors and became their guest. He was a doctor of the people and a Turkophile; in every place he visited, he ate the peasants' food, drank their buttermilk, and learned their health and social problems... He had the courage to tell of both the diseases [he encountered] and the treatments [prescribed] to his students, the university circles, and state [provincial] and government officials through his writings, lectures, and conferences. ${ }^{53}$

Similarly, Dr. Muzaffer Sertabiboğlu, recalled:

I am one of the first graduates of the Ankara Medical Faculty. My diploma has the number 68 on it. I am one of those who was nourished by the wisdom of [Albert] Eckstein. [...] [He] considered Turkey as his second home and was able to lecture without translators by learning Turkish in a short time. ${ }^{54}$

Professors Behçet Tahsin Kamay and Muzaffer Sertabiboğlu both referred to Albert Eckstein as their hoca - an affectionate old Turkish term for the "Teacher" with a capital "T."

Just prior to his departure from Turkey, Professor Eckstein was working on three different children's hospital projects for the city of Ankara. Despite accepting the projects with enthusiasm, the government transferred all promised funds to other projects at the last minute, making Professor Eckstein deeply disappointed. In his last letter to the Dean of the Faculty of Medicine, in which he told about his accepting the pediatrics chair in Hamburg, Professor Eckstein insisted on the importance of the establishment of a well-equipped children's clinic. This short but emotional letter left a strong impression that Professor Eckstein was occupied with the needs of the children of Ankara even while leaving the city. Albert Eckstein died on 18 July 1950, in Hamburg, six months after he left Turkey.

\section{İhsan Doğramac1}

During his 1938 travels in Anatolia, a chance meeting between Eckstein and a young doctor in Manisa turned out to have a profound impact, not only on the young doctor's individual career, but also on the future of pediatrics in Turkey.

53 Ibid., 34:120.

54 Ibid., 34:121. 
Eckstein met İhsan Doğramacı during this sojourn. Doğramacı had just graduated from İstanbul University's Faculty of Medicine, and had not yet selected his field of specialization. Eckstein invited Doğramacı to participate in his trips across Anatolia, an invitation, which paved the way for years of fruitful academic collaboration. This co-operation contributed greatly to the development of pediatrics in Turkey. Doğramacı specialized in pediatrics treating children's illnesses, but he ultimately became a public figure devoted to the establishment and development of educational institutions, centers, faculties, and two universities, one public and the other private. As a doctor, he recognized that the education of generations is as important as their health.

İhsan Doğramacı was born on 3 April 1915 in Erbil. He graduated from the International College of the American University of Beirut in 1932 and from İstanbul University Faculty of Medicine in 1938. He specialized in pediatrics at the Ankara Numune Hospital as an assistant of Albert Eckstein and left in 1940 for Baghdad. In 1942, he married Ayser the daughter of the former prime minister of Iraq, Hikmet Süleyman and went to the United States to do scientific research. In the US, Doğramacı worked in the pediatric departments of Harvard University and Washington University in St. Louis. After returning to Turkey in 1947, İhsan Doğramacı joined the Ankara University Faculty to specialize under Professor Albert Eckstein. Among his colleagues were Dr. Bahtiyar Demirağ, who received his training in Berlin between 1936-1939, Dr. Selahattin Tekand, Dr. Sabiha Cura (Özgür) and Dr. Neriman Olgür. ${ }^{55}$ In 1949, İhsan Doğramacı was appointed Assistant Professor, and in 1954 became full Professor. The same year, İhsan Doğramac1 initiated the establishment of the Child Health Institute, which later became the Hacettepe Children's Hospital and in 1967, the Hacettepe University.

55 Bahtiyar Demirağ had his training in İstanbul, and Germany between 1936-1939. He replaced Albert Eckstein in Ankara Numune Hospital after 1950. Together with him, the Ankara University faculty established Antalya-Akdeniz University and Diyarbakır-Dicle University pediatric clinics. Demirağ also established a children's hospital, which still continues to serve as the children's hospital at Ankara University. See Nejat Akar, Prof. Dr. Bahtiyar Demirağ: Biography of the Founder of Ankara University Medical Faculty's Paediatrics Chair. Sabiha Cura went to Izmir and initiated a pediatrics clinic at Ege University. For several years she contributed to the establishment of Social [public health] Pediatrics within Ege University. Her brother Alphan Cura followed her as a pediatrician, and developed Ege University's Department of Pediatrics. Selahattin Tekand was also appointed to İzmir, to Dr. Behçet Uz Children's Hospital. Neriman Olgür went to İstanbul and worked in the pediatrics clinic in Haydarpaşa Numune Hospital. 
Figure 3. Dr. Doğramacı and Dr. Eckstein.

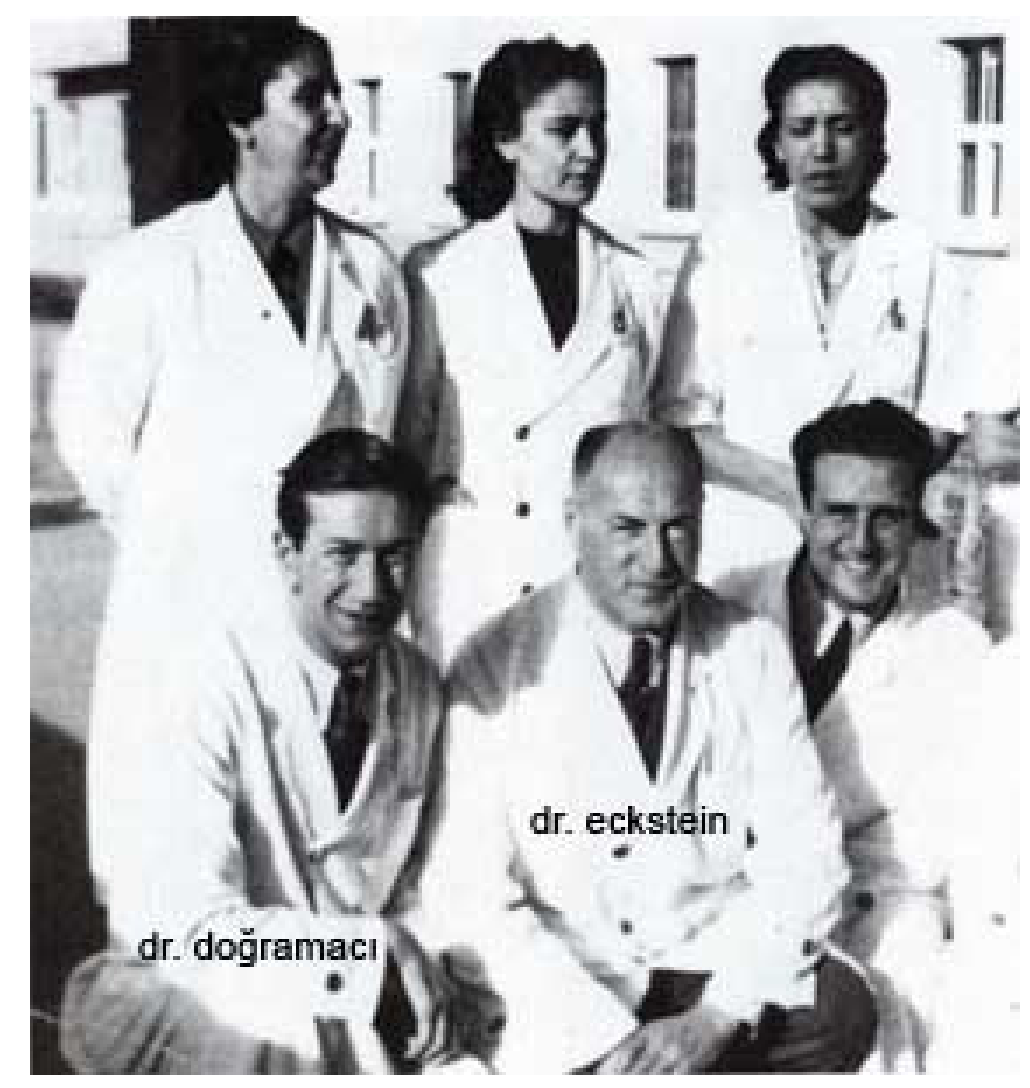

In an interview with one of the authors, İhsan Doğramacı shared the view that he would not have been a pediatrician had he had not met Dr. Albert Eckstein. ${ }^{56}$ Although Pediatrics was not his initial choice, to ameliorate child care became a powerful field of attraction for him, and became the focal point for his future career. As Albert Eckstein's dedication to children sparked his enthusiasm for the field, İhsan Doğramacı struggled with the difficult task of improving health care policies and developing medical institutions in Turkey. Professor Doğramacı remembers Professor Albert Eckstein as a friendly teacher with very strong humanitarian concerns. "Professor Eckstein was a very modest man, attentive to the opinions of the young doctors. He was eager to learn from his young colleagues, so he was often asking questions to students about the subjects they studied. He was a very thoughtful person. He was always ready to offer help to other people, especially his colleagues, even in their most trivial problems. He never disdained from getting into trouble in order to help someone. To commemorate Professor Eckstein's contributions to Turkish pediatrics as a doctor, and as a teacher, is my principal duty.". 57

56 Oral communication on 16 July 2007. The authors would like to thank Professor İhsan Doğramac1 for sharing his memories of Professor Albert Eckstein.

57 Ibid., 58. 
Professor Doğramacı's recollections about the genial work environment created by the émigrés concur with recollections of many other former students. For the students in Turkey, the émigrés' method, which depended on dialogue, was an unconventional style of teaching, a contrast to straight lectures. ${ }^{58} \mathrm{~A}$ new pedagogy concept was mobilized as reflected in the Minister of Education Reşit Galip's speech, delivered at Istanbul University on the occasion of the 1933 Reform. Accordingly, "the Professor is not a machine for giving lectures, but is a resource to the students --one who inspires them to investigate and question, one who guides them and one who is able to sustain their enthusiasm for study and research. The real professor is himself a lifelong student" ${ }^{59}$ Reflected in Galip's words, that the encounter of Eastern and Western pedagogy was a challenging rite of passage for students in the young Republic's only university at that time. ${ }^{60}$ The non-authoritarian atmosphere of the new academe challenged the inherent teaching hierarchy, and students found relatively more space to express themselves and openly discuss their views. This facilitated İhsan Doğramaci's blossoming. Studying in the United States after graduation, Doğramacı observed the pediatrics clinics, the medical education policies all of which honed his idealism. In his mind, he formulated the basic foundations of his dream hospital.

Professor İhsan Doğramacı took a keen interest in the development of a new medical faculty in Ankara. His motives were to extend and open new opportunities for young physicians, to establish a medical information and referral center, and to educate a brand new group of health personnel qualified in preventive pediatrics. ${ }^{61}$ He was also motivated by the unfulfilled desire of Prof. Albert Eckstein to establish a modern, full service children's hospital in Ankara. As a result of his insistent efforts, Ankara University's Child Health Institute gradually developed into a children's hospital, Hacettepe Children's Hospital, then into a leading university, the Hacettepe University. Despite the opposition of a pressure group, which claimed

58 There are several testimonials that express the émigré professors' keen interest in building confidence in the students, and supporting thought exchange. The famous Professor of Law Ernst Eduard Hirsch deals with this pedagogical problem in detail in his memoirs. See Ibid., 32: 248-258. For testimonials of Professor Albert Eckstein's students, Ibid., 34, pp. 117-125.

59 "Milli Eğitim Bakanı Sayın Reşit Galib'in Demeci [The Speech of Minister of Education Mr. Reşit Galib]," in Ernst Hirsch, Dünya Üniversiteleri ve Türkiye'de Üniversitenin Gelişmesi, (İstanbul: 1950), pp. 310-319.

60 For İhsan Doğramac1's overall views on the 1933 reform, see his paper "Higher Education Reform in Turkey: The University in the Service of the Community: Results after Three Years of Application", Higher Education in Europe IX, (October-December 1984), pp. 7482.

61 See "The Proposal for the Establishment of a Children's Medical Center in Ankara, Turkey" quoted at length in Howard A. Reed, "Hacettepe and Middle East Technical Universities: New Universities in Turkey”, Minerva, 2, (1975): pp. 213. 
that a new Faculty of Medicine would divide the Ankara University faculty and cause unrest, Professor Doğramacı pursued his dream.

Development of a new Faculty of Medicine was a long and exhausting crusade because it was an expensive and complicated process. Nevertheless, there was a competent group of physicians behind Professor Doğramac1, who shared his goal of improving health care in Ankara. The new faculty enhanced the standards of medical services, and dramatically contributed to expanding and to modernizing health care delivery in the country. During the 1960s, a number of pediatric clinics were added and the quality of health care significantly improved. Under the umbrella of the Child Health Institute, Doğramacı established a School of Physiotherapy and Rehabilitation, Schools of Nursing, Dietetics and Nutrition in Ankara, were also established during the 1961-1962 timeframe. All of these were Turkey's first of their kind in offering medical education at the university level. ${ }^{62}$ Doğramacı served as the first Dean of Hacettepe University's Faculty of Medicine from 15 July 1963 to 4 November 1963, and as the rector of the Ankara University between 1963 and $1965^{63}$

On 8 July 1967, Hacettepe received university status and İhsan Doğramac1 became its rector. In less than ten years, it became a well-established center for scientific research with " 14 Faculties, 8 higher schools, 40 institutes, 20 departments, two main campuses, and a staff of 1,048 , including 98 associate professors and 83 professors, and over 7,500 students". ${ }^{64}$

İhsan Doğramacı served as the rector of Hacettepe until 1975, and in 1981, with the Law of Higher Education (Law No. 2547) higher education in Turkey drastically re-organized, Professor Doğramacı was elected President of the Council of Higher Education. He administered the activities of all higher education until 1992. In 1984, İhsan Doğramacı established Bilkent University in Ankara, the first private university in the country. Thus while concentrating on the advancement of pediatrics, Professor Doğramaci simultaneously worked on the development of higher education in Turkey. That became a lifelong interest of his. In recent years, İhsan Doğramacı envisioned the establishment of university-level education centers of excellence. In 2007 the first such center opened in Erzurum.

62 James P. Smith notes that "Turkey was the first European country to provide facilities for undergraduate nursing education, followed by the United Kingdom." See Journal of Advanced Nursing, 3, (February 2006), p. 259. By 1986, four European countries other than Turkey were providing a basic university level nursing education. See S.A. Özsoy. "The Struggle to Develop Nursing Research in Turkey”, International Nursing Review, 3, (2007), pp. 243-248.

63 One of İhsan Doğramaci's important scientific contributions made in this period is on porphyrias. See "Porphyrias and porphyrin metabolism with special reference to porphyria in childhood", Adv. Pediatr., 13, (1964), pp.11-63.

64 Ibid., 63:212. 
Many medical specialists, who are now esteemed names in modern Turkish medicine, played key roles in Hacettepe's history. Several young doctors from Hacettepe Medical Faculty later went to United States for further studies. Upon their return, some received an established chair. Among these were pediatrician Dr. Abdullah Kenanoğlu Professor Doğramacís assistant who studied radiology at Harvard, returned and established modern radiology in Hacettepe. Şinasi Özsoylu studied at Washington University in St. Louis, and Sevinç Oral at the Harvard School of Public Health. Both returned to Turkey and played important roles in Hacettepe's development. Eren Kum and Nebahat Büyükoktay after post graduate training in the US returned to revitalize nursing care at Hacettepe.

\section{Burhan Say}

In 1957, Burhan Say, an assistant professor of pediatric hematology, came to Ankara from United States, to support İhsan Doğramacı in Hacettepe's development. He was one of the leaders in establishing the Hacettepe hospital, a member of the team, which quickly established a dynamic work force and made the standards of medical education and care a competitive issue. Say was among the generation of physicians, who actually witnessed the contributions of the émigré professors to the development of medicine in Turkey. He is one of the few Turkish physicians whose name is associated with a disease they first recognized. ${ }^{6}$

Burhan Say was born on 26 February 1923 in İstanbul. He attended Ankara Lycee, and upon his graduation in 1940, he went to İstanbul to study Medicine. Having finished his studies at the İstanbul University Faculty of Medicine in 1946, Say took another journey, but this time to a foreign country. He specialized in pediatrics in the Nashville Tennessee Faculty of Medicine in 1951 and in pediatric hematology at Temple University in Philadelphia between 1952-1953. In 1960s, Say returned to Turkey and joined the Hacettepe Children's Hospital. He became an associate professor in 1960, and full professor in 1964, a year after the Hacettepe University Faculty of Medicine received its legal status.

Professor Say recalls that his first meeting with Eckstein was in 1948 when visiting him and İhsan Doğramacı in the pediatrics clinic of Ankara Numune Hospital, to ask for guidance about some career opportunities. The clinic, he recollects, was "a very democratic one" and Eckstein, was "a very different professor, when com-

65 In 1937 careful inspection of mouth ulcers and infection of the eyes symptoms by Hulusi Behçet revealed a new disease of viral origin. It is now referred to worldwide as Behçet's Disease. 
pared to the others" ${ }^{66}$ It is interesting that a 1946 graduate of Istanbul University's Faculty of Medicine, almost 15 years after the 1933 reform, sees the democracy Prof. Eckstein had established in his clinic as a distinguishing feature. This indicates that the 1933 reform's task of transforming the old education system, in which the authority of a professor was grounded in his status as a professor, and teaching was seen as a one-way transformation of knowledge, was a big challenge. It also indicates, that the reform could not completely eradicate the roots of the old pedagogical mentality.

Although education as an interaction process did not completely turn into an act grasped by all professors, the efforts for improving educational institutions both in quality and in number continued. In the second half of 1960s, the Hacettepe faculty undertook the difficult task of establishing pediatrics clinics all over Anatolia. Young doctors moved in groups to provincial towns like Erzurum, Kayseri, Samsun, and Trabzon. In 1966, the year Burhan Say went to Harvard with a Fullbright scholarship to study genetics, a new medical Faculty opened doors at the Atatürk University in Erzurum. Howard A. Reed provided an account of the establishment of new medical faculties in provincial towns of Turkey:

In 1965-66, the governing body of Hacettepe undertook to develop a medical faculty for Atatürk University in Erzurum, sending Professor Ali Ertuğrul as dean with 33 young colleagues. This represented nearly a third of Hacettepe's academic staff. Within three years, the new medical school was working closely with some 40 rural health clinics. When the Hacettepe group arrived there were only six physicians in Erzurum. By 1973, there were more than 200, most of them products of the new medical school, and others who were attracted by it. In 1974, the medical faculty of Atatürk University agreed to form the core and develop a medical faculty for the new Çukurova University in Adana. In the meantime, the Hacettepe medical faculty itself is sponsoring a branch medical faculty in Kayseri, and other new ones in Eskişehir, Samsun, Sivas, and Trabzon, largely by means of basic science training for the first three years of medical studies, primarily in Ankara, then providing the clinical training in affiliated hospitals in those cities where new universities are being founded. ${ }^{67}$

The development continued in many parts of the country resulting in an elevated consciousness about modern medicine, and a relatively high quality of clinical health care. Additionally, the pediatrics clinics of İstanbul University made major advances to child health in Turkey during this period.

66 Written communication on 13 September 2007. The authors would like to thank Professor Burhan Say for sharing his memories of Professor Albert Eckstein and remarks on Professor İhsan Doğramaci.

67 Ibid., 63:219. 
Between 1968 and 1973, Say worked at Hacettepe University, combining pediatrics, hematology and genetics, and established the first genetics department in the country. His primary supporter during those years, he says, was Professor İhsan Doğramac1, who "came with new projects almost every day, and lavished endless energy on them to make advances". ${ }^{68}$ In 1973, Say left for Tulsa. He worked at the University of Oklahoma as a clinical professor. With his colleagues, he published eleven new malformation syndromes. Say also established a department of genetics at the Tulsa Children's Hospital, and contributed to the establishment of the department of molecular biology and genetics at Bilkent University in Ankara.

The 1980s saw a rapid expansion of the private health care sector in Turkey. The Ministry of Health prepared new policies to attract private sector investment in health services and successfully achieved an increase in the number of private hospitals. It, however, could not entirely succeed in ameliorating inequalities in the distribution of health care, since the private sector chose to concentrate in big cities. With the increasing popularity of private hospitals, a decline in confidence of public health services followed. Unfortunately, Turkey has relatively few health personnel compared with other countries. Currently the ratio is approximately one doctor and one nurse per 1000 population, the lowest figure among the 51 countries in WHO's European Region. ${ }^{69}$

\section{Concluding Remarks}

The careers of Albert Eckstein, İhsan Doğramac1, and Burhan Say provide important evidence of how medical education, health care services and the very approach to higher education were transformed in Turkey. Their respective histories make one think about the rise of humanitarian values out of the cinders of a dark period of hatred. They also speak of the profound transformation Turkey underwent in the realms of education within a short period of time. With the accounts of Prof. Doğramacı and Prof. Say, this article covered an important albeit a limited aspect of the émigrés contribution to Turkey's transformation from a country with underdeveloped pediatrics clinics in the 1930s to a country with practitioners well-informed in medical science, who left to history syndromes named after them in the 1970s.

The émigré physicians on whom the people of Turkey relied for transmitting modern medicine, had to deal with poor sanitary conditions, underdeveloped clinics and insufficient financial support for equipment and facilities needed. More importantly, they had to deal with the image of a physician in minds of a predominantly traditional society used to dealing with health problems by trusting in God's

68 Ibid., 68.

69 Ibid., 7:77. 
omnipotence. The first generation students of the émigrés had to deal with a lack of funds and the slow developments. However, they worked in a relatively transformed environment. Difficulties in establishing a practice were reduced during their studies at the university. The features were by no means uniform across the hospitals or clinics, but over time there was a noticeable improvement at all. The lay person's view of the medical profession changed for the better because of the rapid developments in the overall conditions of education, health, and hygiene.

By the time İhsan Doğramacı became a professor, there was a well-educated generation of young doctors, and improved conditions for practice. To be sure in many ways these conditions, too, needed continuous upgrades. Clinics were established all over the country, encouraging enterprising young practitioners. The highly trained practitioners encountered a transformed society. Transformation of higher education accelerated rapidly as well. By the late 1960s gender-egalitarianism at schools increased, as did a larger public role for women. In 1970, Turkey had a higher percentage of women "in several key professions, including university teaching" than did most Western countries. ${ }^{70}$ Of the thirty-nine universities founded after 1991 twenty-four were private, and there was a remarkable rise in the number of students recruited to universities. ${ }^{71}$ Currently over 1.7 million high school seniors sit for the university entrance examination each year.

The émigré physicians' expertise raised the standards of medical education significantly in Turkey. Albert Eckstein gained a high public profile not only with his expertise, but also with his friendly attitude toward his students and colleagues, and his sympathetic treatment of patients. Three significant outcomes in Turkey are widely attributable to Eckstein: he introduced the ways and the means of collecting public health data and using the resulting statistics in planning and implementing public heath services throughout the country; he eradicated Noma, and thereby reduced Noma related deaths to zero. Through improved pre and postnatal care practices that he introduced, he greatly reduced infant mortality rates. His knowledge and skills have been an inspiration to colleagues and medical students.

Turkey provided a safe haven for over 1,000 individuals who escaped the Nazis. There were greater numbers of émigrés in many other countries, but in Turkey their sojourn left the greatest impact. The expellees from Germany and Austria modernized the country's higher education and some of the most important aspect

70 Nikki R. Keddie, Women in the Middle East: Past and Present (Princeton: Princeton 2006), p. 83. Today Turkey is several decades ahead of western countries, particularly the United States, in terms of percentages of women working as physicians, (26\%), and university professors $(42 \%)$. This is also true at the senior level administration of universities, and government agencies. See Ibid., 15, 443.

71 Fatma Mizikac1, "Prospects for European Integration: Turkish Higher Education", Higher Education in Europe, 1, (2005), pp. 67-80. 
of its infrastructure. They played very important roles in the training and guidance of a new generation of students, who went on to innovate further developments. It is fair to say that while the émigrés' sojourn in Turkey was definitely an episode, their impact on that country and their legacy is much closer to being an epoch. Several prominent physicians in Turkey, who had been students of the émigrés, have recently published their memoirs. The future will most probably yield more diaries, autobiographies and the like, which will carry the potential of extending our knowledge of the period, and opening up new horizons in the historical studies of the 1933 reform and the immigration of the noted professors from Germany to Turkey. ${ }^{72}$

Arnold Reisman, $\mathrm{PhD}$, is a Fellow of the American Association for the Advancement of Science. Çimen Günay-Erkol is PhD candidate in Turkish Studies at Leiden University, the Netherlands, and instructor in the Faculty of Arts and Sciences at Ozyegin University, Turkey.

72 For some examples of such recent books, see Tarı Minkari and Figen Şakac1, Mizah Zekanın Zekatıdır: Tarık Minkari Kitabı (İstanbul: 2007), Mehmet Zaman Saçlıŏlu. Güneş Umuttan Şimdi Doğar: Türkan Saylan Kitabı (İstanbul: 2004). 